Discussion Paper No. 09-037

\title{
The Optimal Choice of a Reference Standard for Income Comparisons: Indirect Evidence from Immigrants' Return Visits
}

Holger Stichnoth

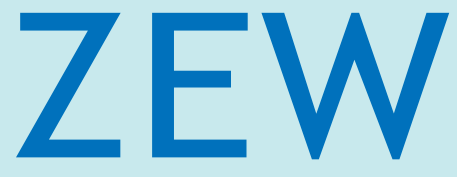

Zentrum für Europäische Wirtschaftsforschung $\mathrm{GmbH}$ Centre for European Economic Research 
Discussion Paper No. 09-037

\section{The Optimal Choice of a Reference Standard for Income Comparisons: Indirect Evidence from Immigrants' Return Visits}

Holger Stichnoth

Download this ZEW Discussion Paper from our ftp server:

ftp://ftp.zew.de/pub/zew-docs/dp/dp09037.pdf

Die Discussion Papers dienen einer möglichst schnellen Verbreitung von neueren Forschungsarbeiten des ZEW. Die Beiträge liegen in alleiniger Verantwortung der Autoren und stellen nicht notwendigerweise die Meinung des ZEW dar.

Discussion Papers are intended to make results of ZEW research promptly available to other economists in order to encourage discussion and suggestions for revisions. The authors are solely responsible for the contents which do not necessarily represent the opinion of the ZEW. 


\section{Non-technical summary}

In this paper I test the prediction that the reference standard for income comparisons increases in a person's productive ability, which is proxied for by education. The prediction is derived from a model by Falk and Knell (2004), who are among the first to endogenize the reference standard. In their model, individuals trade off a self-enhancement motive (choosing a low comparison income to make oneself feel good) against what Falk and Knell call a self-improvement motive: aiming high in one's comparison in order to be more motivated, and thus more productive, at work. Falk and Knell's main result is that, at least under their assumptions about functional form, the optimal comparison income increases in a person's productive ability.

The difficulty with any empirical test is that, to my knowledge, the reference standard for income comparisons is not observed in existing large data sets. As a way around, I propose to focus on immigrants (an application that Falk and Knell themselves suggest), and I assume that return visits are a way of adjusting one's standard for income comparisons. By extending Falk and Knell's model in this way, I am able to derive the two predictions that other things equal better educated immigrants (1) will return to their former home countries less often, and (2) will have greater difficulty feeling at home when they do return to their countries of origin.

I test the two predictions using data from five waves of the German Socio-Economic Panel, which has a large number of observations on immigrants and a rich array of questions related to immigration. Both predictions are tentatively confirmed. In probit and ordered probit models controlling for a large number of other factors, I find that better educated immigrants are indeed less likely to have visited their countries of origin, and that when they did return for a visit, they report greater difficulty feeling at home. The effects are statistically significant, but rather small in size: a one standard deviation (i.e., about 2.5 years) difference in years of schooling reduces the probability of a return visit by approximately 0.7 percentage points, and is associated with a probability of feeling at home straight away that is lower by about 1.5 percentage points. Both marginal effects are small compared to the marginal effects of variables such as household income, distance to the country of origin, or dummies for having left the country of origin because of a war or because of a lack of political freedom. 


\section{Das Wichtigste in Kürze (German summary)}

Das vorliegende Papier testet die Vorhersage von Falk und Knell (2004), dass eine höhere Produktivität ceteris paribus zu einem höheren Referenzstandard für Einkommensvergleiche führt. Im Modell von Falk und Knell ergibt sich der optimale Referenzstandard aus einem Trade-off zwischen zwei Motiven: Einerseits profitieren Individuen von einem möglichst niedrigen Referenzstandard, da sie bei einem Vergleich entsprechend positiv abschneiden. Andererseits wirkt laut Falk und Knell ein höherer Referenzstandard motivierend und senkt dadurch die Kosten eines gegebenen Arbeitseinsatzes. In ihrem Modell lässt sich nun zeigen, dass Personen mit höherer Produktivität einen Anreiz haben, auch einen höheren Referenzstandard zu wählen.

Diese Vorhersage lässt sich jedoch nicht ohne Weiteres empirisch überprüfen, da der Referenzstandard für Einkommensvergleiche in Datensätzen mit größerer Fallzahl in der Regel nicht beobachtet wird. Die Idee des vorliegenden Papiers ist es nun, zwei indirekte Tests durchzuführen. Diese Tests beruhen auf der Annahme, dass für Einwanderer Besuche in ihren Herkunftsländern einen Einfluss auf den Referenzstandard für Einkommensvergleiche haben. Ich leite die zwei Vorhersagen her, dass (1) Einwanderer mit höherer Ausbildung (als Proxy für die Produktivität) seltener zu Besuchen in ihre Herkunftsländer zurückkehren und (2) dass sie, wenn sie denn zurückkehren, größere Schwierigkeiten haben, sich heimisch zu fühlen.

Ich teste die beiden Vorhersagen mit fünf Wellen des Sozio-ökonomischen Panels (SOEP), einem Datensatz mit einer großen Zahl von Beobachtungen zu Einwanderern und mit zahlreichen Variablen zu Themen der Migration. Beide Vorhersagen werden bestätigt. Probit- und Ordered-Probit-Modelle zeigen, dass Einwanderer mit höherer Bildung in der Tat seltener zu Besuchen zurückkehren und dass sie bei ihren Besuchen größere Schwierigkeiten haben, sich heimisch zu fühlen. In allen Modellen sind die Zusammenhänge statistisch signifikant, aber eher schwach. Ein Unterschied von einer Standardabweichung (das heißt, von 2,5 Schuljahren), reduziert die Wahrscheinlichkeit eines Besuches um ungefähr 0.7 Prozentpunkte. Auch für den zweiten Test ergibt sich ein zwar signifikanter, aber nur kleiner Effekt. Andere Variablen, wie etwa das Haushaltseinkommen, die Entfernung zum Herkunftsland oder politische Gründe für die Auswanderung sind deutlich wichtigere Einflussfaktoren. 


\title{
The Optimal Choice of a Reference Standard for Income Comparisons: Indirect Evidence from Immigrants' Return Visits
}

\author{
Holger Stichnoth \\ ZEW Centre for European Economic Research, Mannheim* \\ Paris School of Economics
}

June 25, 2009

\begin{abstract}
I propose two new tests of Falk and Knell's (2004) prediction that individuals' reference income increases with ability. To overcome the difficulty that the reference income is not observed in existing large data sets, I extend Falk and Knell's model to establish a link between immigrants' reference income and their return visits to their countries of origin. I derive the (arguably counter-intuitive) predictions that more educated immigrants are less likely to have returned to their country of origin for a visit, and that they are more likely to have difficulty feeling at home when they do return for a visit. Both predictions are confirmed on four waves of data from the German Socio-Economic Panel. The estimated marginal effects are statistically significant, but rather small in size.
\end{abstract}

Keywords: reference standard, social comparison, immigration, Germany JEL codes: D62, D63, H31, Z13

*ZEW Mannheim, Postfach 103443, 68034 Mannheim, Germany. E-Mail: stichnoth@zew.de. I would like to thank Joachim Frick for helpful comments on an earlier draft of this paper, and the Deutscher Akademischer Austauschdienst (DAAD) for financial support. 


\section{Introduction}

A large number of studies has shown that self-reported satisfaction with one's life or income is correlated with reference group income. ${ }^{1}$ However, a central difficulty in these studies is that the researcher usually does not observe with whom people compare their income. It is typically assumed that people compare themselves to others who are similar in terms of age, gender, education, region, or occupation. Although the conclusions about the importance of relative income for self-reported satisfaction and for observed behaviour (e.g., savings behaviour or the decision to emigrate) may hinge on the assumption about the reference group, the assumption is never tested in these empirical studies.

There is clearly a need to find out more about the determinants of a person's reference group. In this paper I test the prediction that the reference standard (for income comparisons) increases in a person's productive ability. The prediction is derived from a model by Falk and Knell (2004), who are among the first to endogenize the reference standard. In their model, individuals trade off a self-enhancement motive (choosing a low comparison income to make oneself feel good) against what Falk and Knell call a selfimprovement motive: aiming high in one's comparison in order to be more motivated, and thus more productive, at work. Falk and Knell's main result is that, at least under their assumptions about functional form, the optimal comparison income increases in a person's productive ability. Falk and Knell show for 255 students at two universities in Zurich that there is indeed a positive correlation between high-school grade (their proxy for ability) and aspired grade on the final university exam, even controlling for a number of possible common influences. As far as I know, this is the only test of their model so far.

The difficulty with any empirical test is that, to my knowledge, the reference standard for income comparisons is not observed in existing large data sets. As a way around, I propose to focus on immigrants (an application that Falk and Knell themselves suggest), and I assume that return visits are a way of adjusting one's standard for income comparisons. By extending Falk and Knell's model in this way, I am able to derive the two predictions that other things equal better educated immigrants (1) will return to their former home countries less often, and (2) will have greater difficulty feeling at home when they do return to their countries of origin. These two predictions are counter-intuitive, but can be explained by the efforts of more highly educated immigrants to maintain the higher native reference standard. The use of education as a proxy for ability follows the test

\footnotetext{
${ }^{1}$ See the recent survey by Clark et al. (2008). McBride (2001) and Luttmer (2005) are two of the best-known studies for the U.S.; for Germany, see the studies by Ferrer-i-Carbonell (2005), Schwarze and Winkelmann (2005), Schwarze and Härpfer (2007), and D'Ambrosio and Frick (2007).
} 
that Falk and Knell themselves carry out.

I test the two predictions using data from five waves of the German Socio-Economic Panel (for the years 1996, 1998, 2000, 2002, 2004), which has a large number of observations on immigrants and a rich array of questions related to immigration. Both predictions are tentatively confirmed. In probit and ordered probit models controlling for a large number of other factors, I find that better educated immigrants are indeed less likely to have visited their countries of origin, and that when they did return for a visit, they report greater difficulty feeling at home. The effects are statistically significant, but rather small in size: a one standard deviation (i.e., about 2.5 years) difference in years of schooling reduces the probability of a return visit by approximately 0.7 percentage points, and is associated with a probability of feeling at home straight away that is lower by about 1.5 percentage points. Both marginal effects are small compared to the marginal effects of variables such as household income, distance to the country of origin, or dummies for having left the country of origin because of a war or because of a lack of political freedom. The rest of the paper is structured as follows. In section 2 I briefly sketch Falk and Knell's model. Section 3 presents the two empirical tests. Section 4 describes the data, and 5 presents the results. Section 6 concludes.

\section{Falk and Knell's model of endogenous reference income}

Preferences are represented by the utility function

$$
U_{i}=U\left(c_{i}, r_{i}\right)
$$

where $c_{i}$ is own consumption and $r_{i}$ is the consumption of a reference group. Falk and Knell assume that envy dominates altruism, that is, $\partial U / \partial r_{i}<0$. For own consumption, they make the usual assumption that more consumption is preferred to less: $\partial U / \partial c_{i}>0$.

The reference consumption $r$ is usually assumed to be exogenous, which is, according to Falk and Knell, "at odds with findings from social psychology according to which reference standards are to some extent actively chosen" (p.3). To relax this assumption, they postulate that a person's comparison income is the weighted average of an exogenous part $x$ and an actively chosen part $g_{i}$ :

$$
r_{i}=(1-q) x+q g_{i}
$$


where $0 \leq q \leq 1$. Under the assumptions so far, a utility-maximizing individual will set $g_{i}$ equal to zero, for if inter-personal comparisons are dominated by envy and schadenfreude, the best way to feel good is to compare oneself to the very poor. Falk and Knell call this the "self-enhancement motive."

However, introspection as well as casual and more systematic observation (see Wood and Taylor (1991) for references) suggest that this is not the only motive behind the choice of a reference standard. As Falk and Knell note, "people compare themselves to improve their performance. In fact there is a large body of evidence indicating that people perform better if they compare themselves with others who are more successful. Thus performing upward comparisons has an indirect positive effect on overall utility since it facilitates performance" (p.2; italics added). Falk and Knell call this the "self-improvement motive"; it enters the utility function indirectly, through the production function, and therefore falls under what Manski (2000) calls "constraint interaction."

Under these assumptions it is no longer clear that individuals will choose the lowest possible reference standard, and their optimal choice will depend on the relative importance of self-enhancement and self-improvement. What will this relative importance depend on? Falk and Knell focus on productive ability $a_{i}$. They assume that consumption increases with effort $e_{i}$ and with ability $a_{i}$ :

$$
c_{i}=a_{i} e_{i}
$$

where $\partial c_{i} / \partial a_{i}>0$ and $\partial c_{i} / \partial e_{i}>0$. Ability $a_{i}$ is exogenous in their model and is the only source of heterogeneity between individuals.

The cost of effort is given by

$$
k\left(e_{i}, g_{i}\right)=B /\left(g_{i}^{\gamma}\right)^{\delta}\left(1-e_{i}\right)^{1-\delta}
$$

where $\gamma \equiv \theta q$ and $\partial k / \partial e_{i}>0$. The innovation in their model is that $\partial k / \partial g_{i}<0$, that is, the cost of effort decreases with the reference standard: this is the self-improvement motive.

Finally, this cost of effort is incorporated into the utility function, which Falk and Knell assume to be of the form

$$
U_{i}=\alpha \ln \left[(1-\theta) c_{i}+\theta\left(c_{i}-r_{i}\right)\right]-\beta \ln \left[k\left(e_{i}, g_{i}\right)\right]
$$

Falk and Knell show that under these assumptions the optimal reference standard increases with ability, that is, $\partial g_{i}^{*} / \partial a_{i}>0$. The intuition is that a higher reference standard makes effort less costly for everybody $(\gamma$ and $\delta$ in equation (4) being the same for 
everybody), but that individuals with higher productive ability will benefit more from this reduction in the cost of effort. At the extreme, if somebody's consumption is completely unaffected by own effort, he will choose the reference standard as low as possible, since he cannot benefit from the self-improvement effect of a higher reference standard, whereas he suffers from envy like everybody else.

Falk and Knell show for 255 students at two universities in Zurich that there is indeed a positive correlation between high-school grade (their proxy for ability) and aspired grade on the final university exam (their measure of a reference standard), even controlling for a number of possible common influences. As far as I know, this is the only test of their model so far.

\section{Empirical strategy}

The objective of this paper is to find a new empirical test of Falk and Knell's prediction that people's reference income increases in ability. Unfortunately, however, the reference income is not observed in the data sets that I am aware of. Whereas Falk and Knell opt for collecting these data themselves (and are therefore limited to a small number of observations), I propose an alternative way that can be conducted using existing large $N$ data sets. Of course, the tests I propose replace the missing observation on reference income by additional identifying assumptions, so any empirical test is a joint test of Falk and Knell's predictions and my auxiliary assumptions.

The additional assumptions have to establish a link between the unobserved variable "reference income" and some observable variable. I propose to focus on immigrants, an application that Falk and Knell themselves suggest. ${ }^{2}$

\subsection{Probability of a return visit}

My idea is to exploit information on a particular aspect of the migration experience, namely return visits of a migrant to his or her country of origin. I assume that return visits $v_{i}$ have an influence on an immigrant's reference income, that is, $g_{i}=\lambda_{i} v_{i}$, where $\lambda_{i}<0$ if the average consumption in the country of origin is lower than in Germany. The idea is that in this case return visits refresh memories of the lower average income in the country of origin, and that this will lower the immigrant's reference income.

\footnotetext{
${ }^{2}$ The idea that the migration decision is influenced not only by concerns about absolute, but also by concerns about relative income goes back to Oded Stark; his early contributions are collected in Stark (1991).
} 
The relationship between return visits and ability can be derived directly from Falk and Knell's main proposition. Falk and Knell $(2004,433)$ show that the optimal reference standard is given as

$$
g_{i}^{*}=\frac{\beta \delta \gamma}{\mu} a_{i}-\frac{\beta \delta \gamma(1-q)}{\mu} x
$$

Under the additional assumption that I make, the comparative statics result for the optimal number of return visits $v_{i}^{*}$ with respect to ability $a_{i}$ follows directly as:

$$
\frac{\partial v_{i}^{*}}{\partial a_{i}}=\frac{1}{\lambda_{i}} \frac{\partial g_{i}^{*}}{\partial a_{i}}=\frac{\beta \delta}{\lambda_{i} \mu}<0
$$

That is, a model with costless return visits predicts that other things equal, people with higher ability will return less often to their countries of origin.

In reality return visits are not costless, of course. However, while the direct monetary costs of a visit (ticket prices etc.) will depend on the distance to the country of origin (a variable that I can control for), it is plausible to assume that once distance is controlled for, these direct costs are independent of the immigrant's ability (and of the immigrant's education, which I use as a proxy for ability in the empirical part below.) By contrast, other costs, which are less amenable to formal modelling, may well differ by education; for instance, more educated immigrants are more likely to emigrate for political reasons, and they are therefore more likely to be in danger when returning to their country of origin. I attempt to control for such third factors; see the discussion in section 4 below. A last issue that needs to be discussed are the opportunity costs of a return visit. In the basic labour supply model, the opportunity cost of an hour of leisure is the foregone consumption; if the hourly wage differs between people, so will the opportunity cost of leisure. However, the present paper studies not the choice of leisure, but the choice of how this leisure is spent: namely, whether people return to their countries of origin for a visit, or whether they stay in Germany or go to some other country. That is, the choice that is modelled here can be thought of as conditional on a given amount of leisure. The concept of leisure that seems to be most relevant here is the amount of paid vacation an employee is entitled to. In Germany, most employees have between five and six weeks of paid vacation a year; this amount varies mainly by age and tenure and not by education, which is the regressor of interest here. In conclusion, then, the opportunity cost of a return visit in terms of foregone earnings is essentially zero for employees; any variation in the opportunity cost that does exist will mainly be captured by a control for age, and the remaining variation after the adjustment for age is assumed to be independent of education. For the selfemployed, who are free to choose the number of days of vacation, this argument does not hold, and I therefore exclude the self-employed from the estimation. 
To turn equation (7) into an estimable equation, I follow Falk and Knell (2004) and assume that education can proxy for ability $a_{i}$. Moreover, I include a vector of control variables $\mathbf{x}$, which will be discussed below, and an error term $\varepsilon_{i}$ that is assumed to be distributed standard normally and independent of the regressors:

$$
v_{i}^{*}=\zeta_{0}+\zeta_{1} \text { Education }_{i}+\mathbf{x}_{i}^{\prime} \gamma+\varepsilon_{i}
$$

The optimal number of return visits $v_{i}^{*}$ is an unobserved continuous variable. I assume that it is linked to an observed binary variable $d V i$ sit $_{i}$, which measures whether an immigrant has ever returned for a visit to his or her country of origin:

$$
d \text { Visit }_{i}=\mathbf{1}\left(v_{i}^{*}>0\right),
$$

where $\mathbf{1}(\cdot)$ is the indicator function. These assumptions lead to the the probit model

$$
\mathrm{P}\left(\text { dVisit }_{i}=1 \mid \text { Education }_{i}, \mathbf{x}_{i}\right)=\Phi\left(\zeta_{0}+\zeta_{1} \text { Education }_{i}+\mathbf{x}_{i}^{\prime} \gamma\right)
$$

where $\Phi(\cdot)$ is the c.d.f. of the standard normal distribution. The model is estimated by maximum likelihood.

\subsection{Feelings during return visit}

As a second test of Falk and Knell's model, I test the hypothesis that better educated immigrants will have greater difficulty feeling at home when they do return to their countries of origin. Unlike the first prediction, this second prediction is not justified by a theoretical model since modeling feelings appears to be a more difficult task. The informal argument behind the hypothesis is as follows: Falk and Knell (2004) argue that immigrants with higher ability (or education) are more likely to adopt a higher reference income. I add the auxiliary hypothesis that a higher reference income will estrange immigrants from their countries of origin, and that they will therefore have a harder time feeling at home when returning to their country of origin. To test the prediction, I estimate an ordered probit model for immigrant's feelings on their return visits, again attempting to control for common influences. 


\section{Data}

I use data from five waves of the German Socio-Economic Panel (GSOEP), a longitudinal survey of private households which began in $19844^{3}$ The GSOEP over-samples immigrants and contains a rich array of questions related to immigration, which makes the data wellsuited for my purpose. In particular, in the waves of 1996, 1998, 2000, 2002, and 2004, immigrants were asked about return visits to their countries of origin.

For the purpose of this paper, I define an immigrant as a respondent who was born outside of Germany, regardless of nationality at the time of the survey. By contrast, I do not include in this category people who "immigrated" from East Germany before 1989, and Germans who had been living abroad and then returned to Germany. As noted above, I drop self-employed immigrants because for them the assumption that the number of days of vacation is given is less convincing. The resulting estimation sample consists of 7822 person-year observations. Depending on the specification, the actual number of observations will be somewhat lower due to the listwise deletion of missing values. Figure 1 shows the five countries of origin with the most person-year observations.

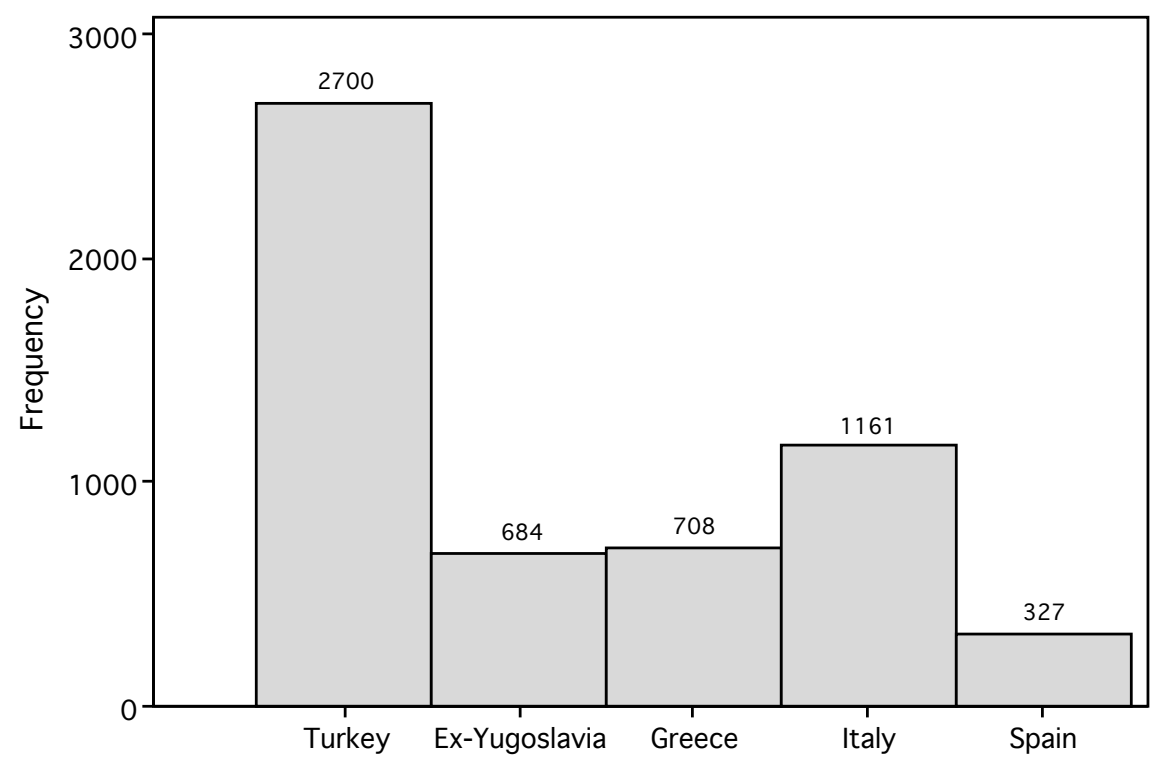

Figure 1: Five countries of origin with most person-year observations

\footnotetext{
${ }^{3}$ The data are available from the German Socio-Economic Panel Study (GSOEP) at the German Institute for Economic Research (DIW) in Berlin. See Wagner et al. (2007) for a detailed description of the GSOEP.
} 


\subsection{Dependent variables}

In the five waves of the GSOEP that I use, immigrants are asked: "since you have come to Germany to live, have you visited your country of origin?" As figure 2 shows, for about $83 \%$ of immigrants the answer is yes.

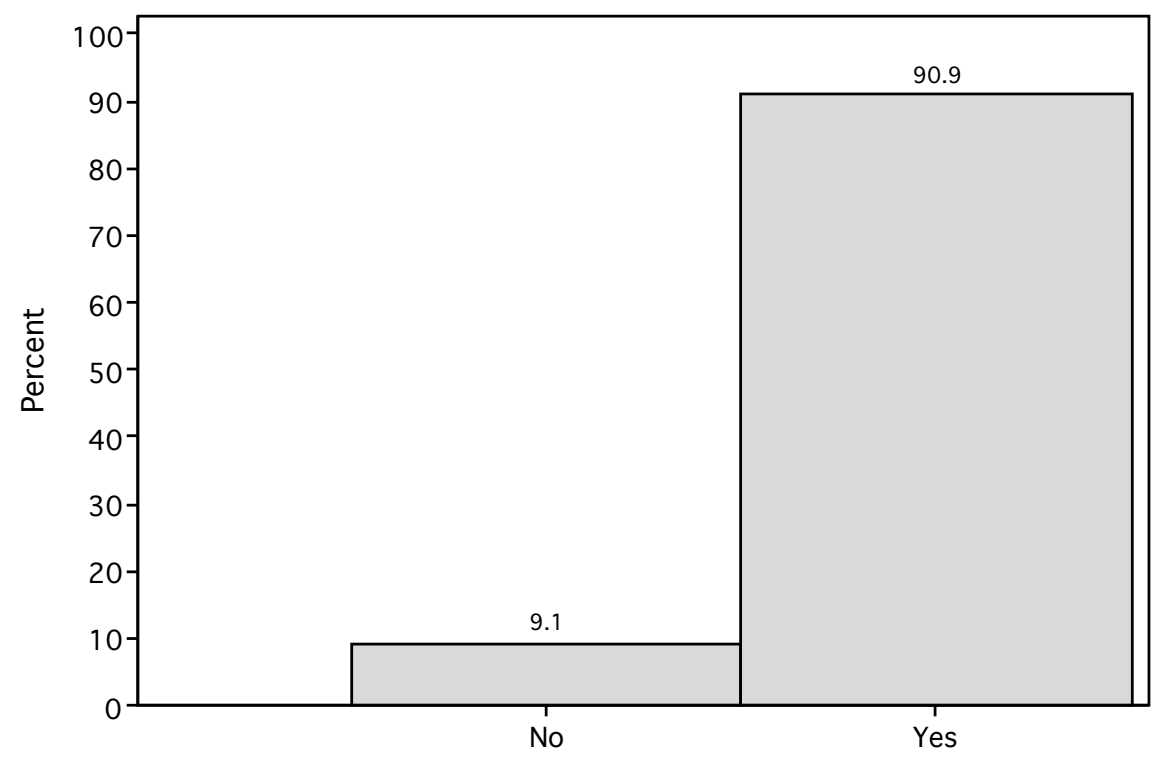

Figure 2: Have you ever visited your country of origin?

There is also a question on how immigrants feel when they do visit country of origin. The question runs: "When some people have lived for a long time in Germany and visit their (former) home country, things may have changed. How is that for you? How do you feel in that situation?" The five answer categories are "I feel at home right away on the first day, as if I hadn't ever been away"; "I feel at home within a short time"; "at first I feel like a stranger, but after a few days I feel at home"; "it takes quite a long time until I feel more or less at home"; "I feel like a stranger in my own country." Figure 3 shows how the answers are distributed in the sample. Most immigrants report to feel at home quickly, but about $20 \%$ of people in the sample report considerable difficulty feeling at home when visiting their country of origin.

\subsection{Regressor of interest}

My regressor of interest is education in years, which I use as a proxy for ability. As table 3 shows, the variable ranges from 7 to 18 years, with a sample mean of about 10.8 years. Table 4 shows that immigrants who have returned for a visit tend to have fewer years 


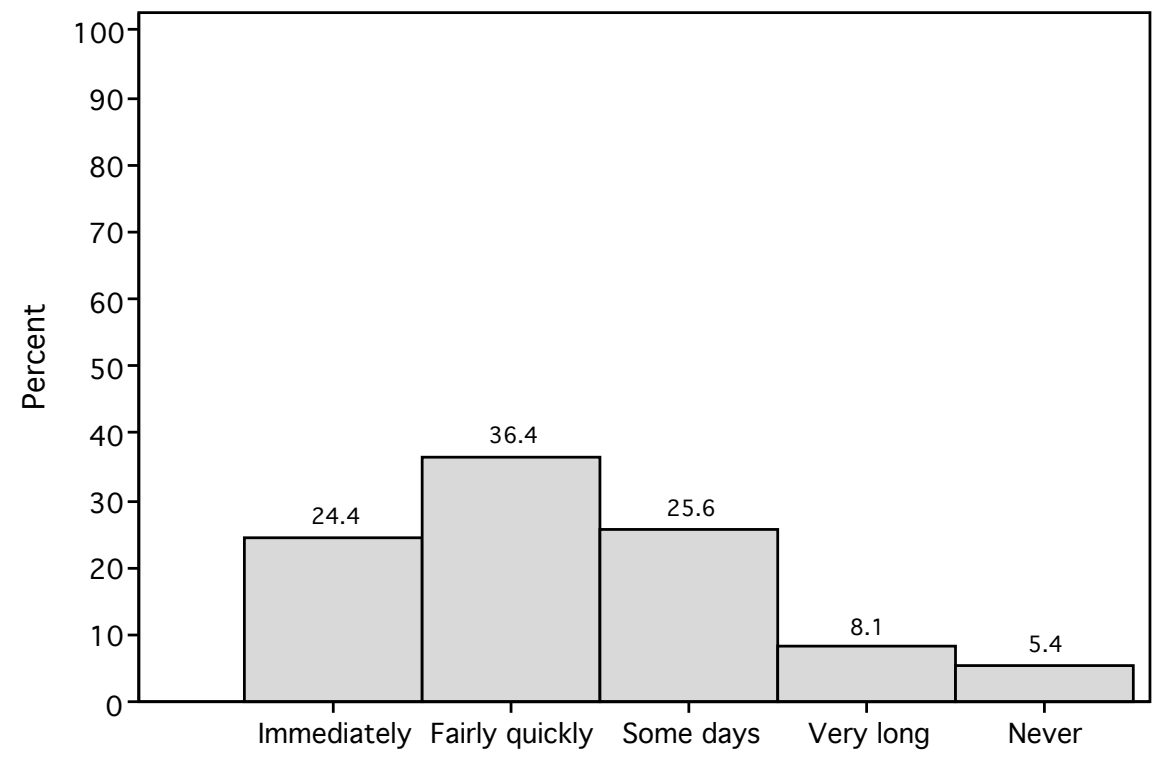

Figure 3: Feel at home in country of origin

of schooling. The means are 9.9 years for those who have returned versus 10.6 years for those who have never returned. The difference in the means is statistically significant. The boxplot in figure 4 shows that the median is lower as well for those immigrants who have returned for a visit.

\subsection{Control variables}

Better education (as a proxy for ability) is correlated with a number of other factors that will also affect the probability of a return visit. As table 5 shows, immigrants who have median or above-median years of schooling tend to be male, younger, of better self-reported health, and tend to live in smaller households than immigrants with below median years of schooling. More years of schooling are associated with much higher household income, a lower unemployment rate, and a higher probability of owning the house or appartment in which one lives. While these correlation patterns also hold true for natives (not reported here), the table shows some interesting associations that are specific to immigrants. Quite strikingly, better educated immigrants are twice as likely to report that they came to live in freedom or to escape a war in their country of origin. By contrast, there is little difference with respect to whether the immigrant still has family abroad; for this variable, the share of positive answers is almost 100\%, regardless of educational level.

Table 4 shows that most of these variables are also associated with the probability of a 


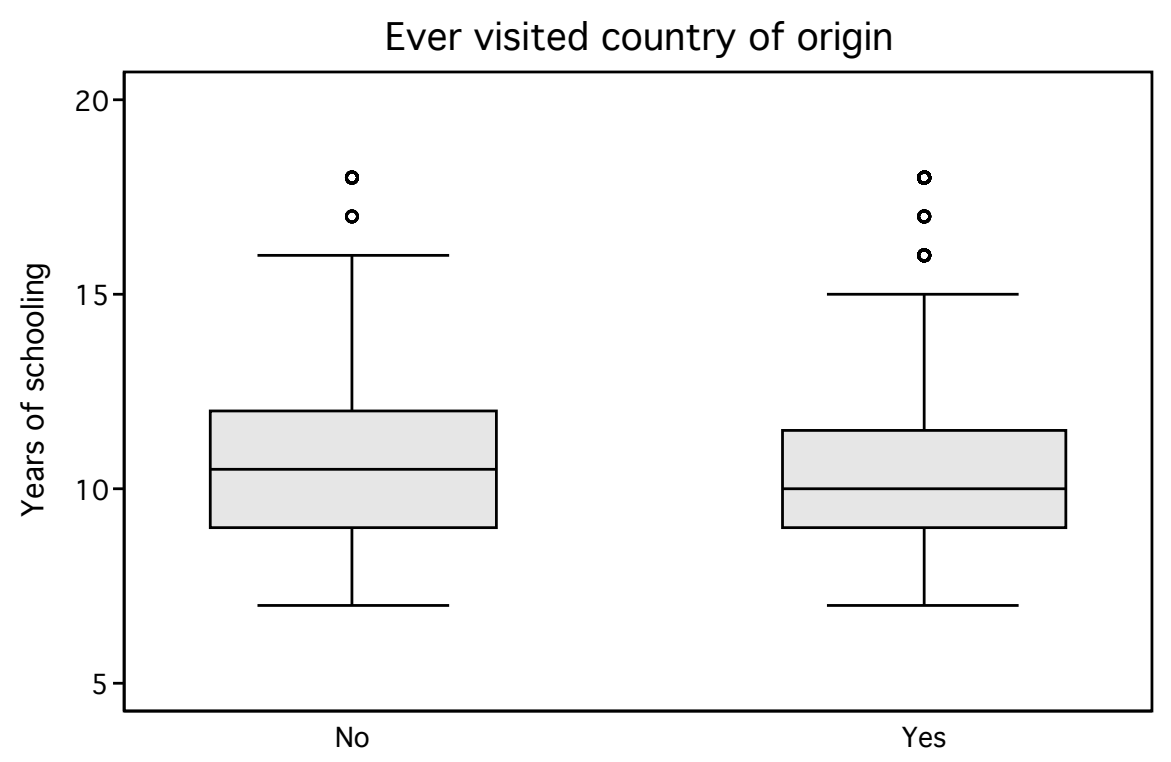

Figure 4: Immigrants who have returned for a visit have fewer years of schooling on average

return visit, and should therefore be controlled for in the multivariate analysis below. For instance, immigrants who have been back for a visit tend to come from countries that are closer to Germany, tend to have higher household income, tend to be older and to have resided in Germany for a longer time, and are slightly more likely to have family abroad. Other striking differences concern the self-reported reasons for migrating: people who came to live in freedom or to escape war are much less likely to have returned for a visit, presumably because they are more likely to be in danger when returning. People who received only a "limited residence permit" when they arrived in Germany are also less likely to have returned for a visit, presumably because they expect having difficulty when they re-enter. ${ }^{4}$ Of course, these are all bivariate associations only; the multivariate analysis below will show whether these differences still exist once other factors are controlled for.

\footnotetext{
${ }^{4}$ The GSOEP contains this information only for the arrival in Germany; the current residence status is not reported.
} 


\section{Results}

\subsection{Probability of a return visit}

Table 1 shows the results from the probit model defined above. The table reports estimated marginal effects at the sample mean.

The prediction that education decreases the probability of a return visit is supported by the data. The estimated marginal effect is -0.007 in the bivariate model. When individual characteristics are controlled for, the marginal effect is larger in absolute value (-0.0096), which mainly reflects the fact that, as seen above, more educated immigrants tend to have higher household income, and that people with higher income tend to return for a visit more often. Once income is controlled for, the negative association between return visits and years of schooling is stronger, as witnessed by the second column. In columns 3 and 4, further controls are added, which drive down the estimated marginal effect of years of schooling. This is most apparent in the comparison between columns 2 and 3 : controlling for distance to the country of origin and for the reasons for emigration reduces the estimated marginal effect from -0.0096 to -0.0025 . As noted above, this reflects the fact that more educated immigrants are more likely to have left their country of origin for political reasons ("left because of war", "came to live in freedom"), and that people who came for these reasons tend to return less often, presumably because a return visit is more dangerous for them. By contrast, the two controls that are added in column 4 (namely, unemployment status and house ownership as a proxy for wealth) affect the estimated marginal effect of education much less.

The estimated marginal effect on years of schooling is -0.0028 in column 4 . This marginal effect is statistically significant, but relatively small in size: a difference of ten years of education (which corresponds to more than four standard deviations!) affects the probability of a return visit by only about three percentage points (recall from above that about $91 \%$ of immigrants have returned to their country of origin for a visit).

To put this marginal effect into perspective, a one standard deviation (i.e., about 2.5 years) difference in years of schooling has a marginal effect of approximately -0.007 , that is, of less than one percentage point. By comparison, the standard deviation of monthly household net income is 1776 euros per month. Hence, a one standard deviation increase in income increases the probability of a return visit by $1.776 \cdot 0.028 \approx 0.05$, that is, by five percentage points (recall that the income variable is expressed in 1000 euros, hence the multiplication by 1.776 and not by 1776). Note that the effects of both education and income are small compared to factors such as distance or having left the country of 


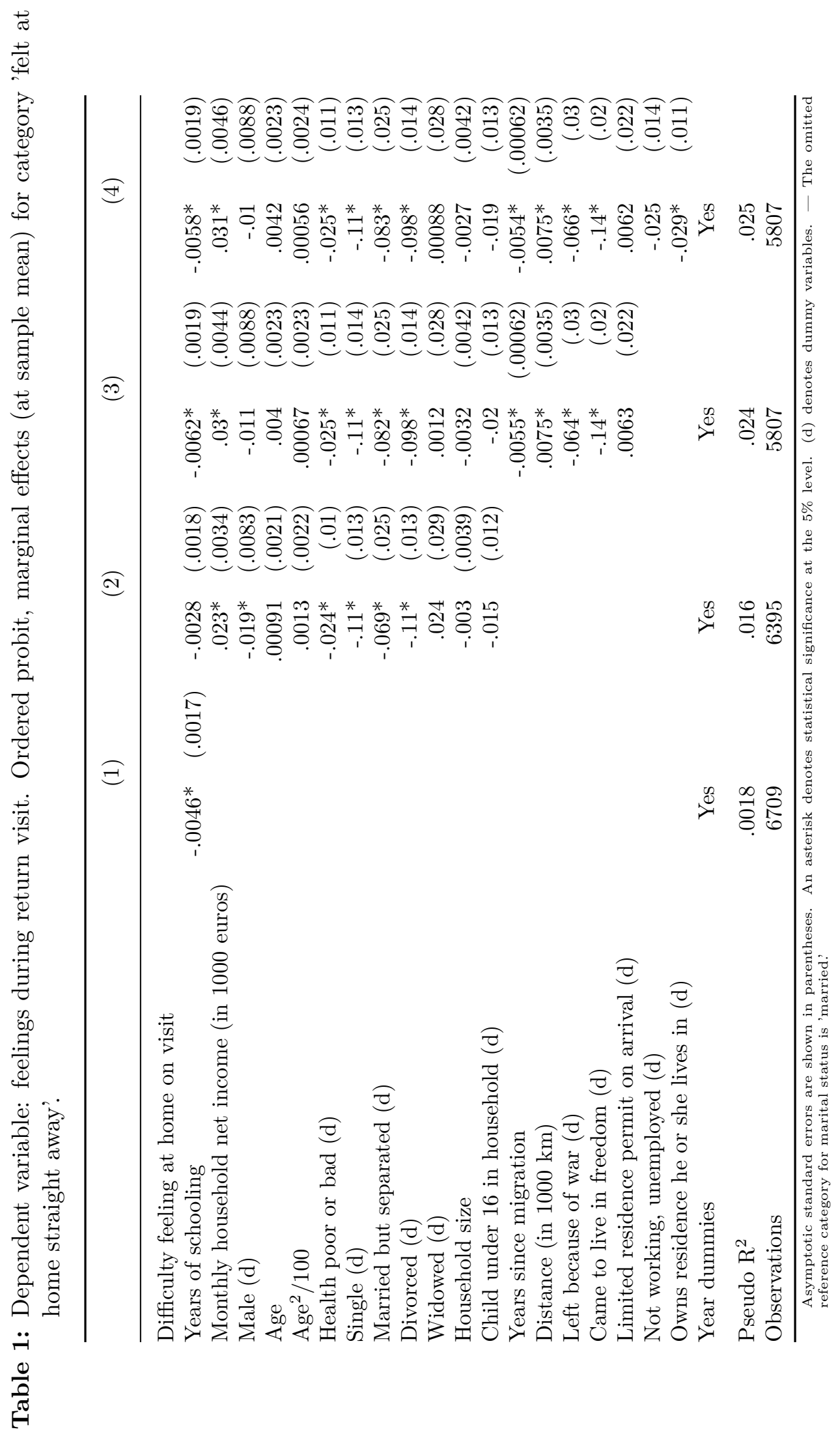


origin because of a war or because of a lack of political freedom.

\subsection{Feelings during return visit}

Table 2 shows estimated marginal effects from an ordered probit model. The dependent variable measures how long it took the immigrant to feel at home when visiting his or her country of origin. The variable has five categories. Only the marginal effects for the first category ( "I feel at home right away on the first day, as if I hadn't ever been away.") are reported. These marginal effects are again evaluated at the sample means of the covariates.

The main result is that the prediction that better educated immigrants have greater difficulty feeling at home is confirmed. This is arguably a counter-intuitive finding since one would expect that more educated people are better at adapting to all kinds of circumstances. As noted, I propose to explain this observation using Falk and Knell (2004)'s model that predicts that better educated immigrants will choose a higher reference income; I add the hypothesis that a higher reference income will estrange an immigrant from his or her (low-income) country of origin, which could explain the difficulty feeling at home. The estimated marginal effects are again statistically significant, but relatively small: a one standard deviation increase in the years of schooling is associated with a probability of feeling at home straight away that is lower by $2.5 \cdot(-0.0058) \approx-0.015$, that is, by 1.5 percentage points. By comparison, having left to "come to live in freedom" is associated with a probability that is lower by about 14 percentage points.

\subsection{Robustness check}

The assumption that return visits to the country of origin lower the reference income is credible only if the average income is lower in the country of origin than in Germany. I therefore re-estimated the models dropping the 2756 immigrants (37\% of the sample) from the EU-15 countries, Switzerland, Norway, the U.S., Canada, Australia, Japan, and Korea. Tables 6 and 7 in the appendix show that the coefficients on education are again negative and, as expected, slightly large in absolute value.

\section{Conclusion}

In this paper I have proposed two new tests of Falk and Knell (2004)'s prediction that individuals' reference income increases with ability. To overcome the difficulty that the 


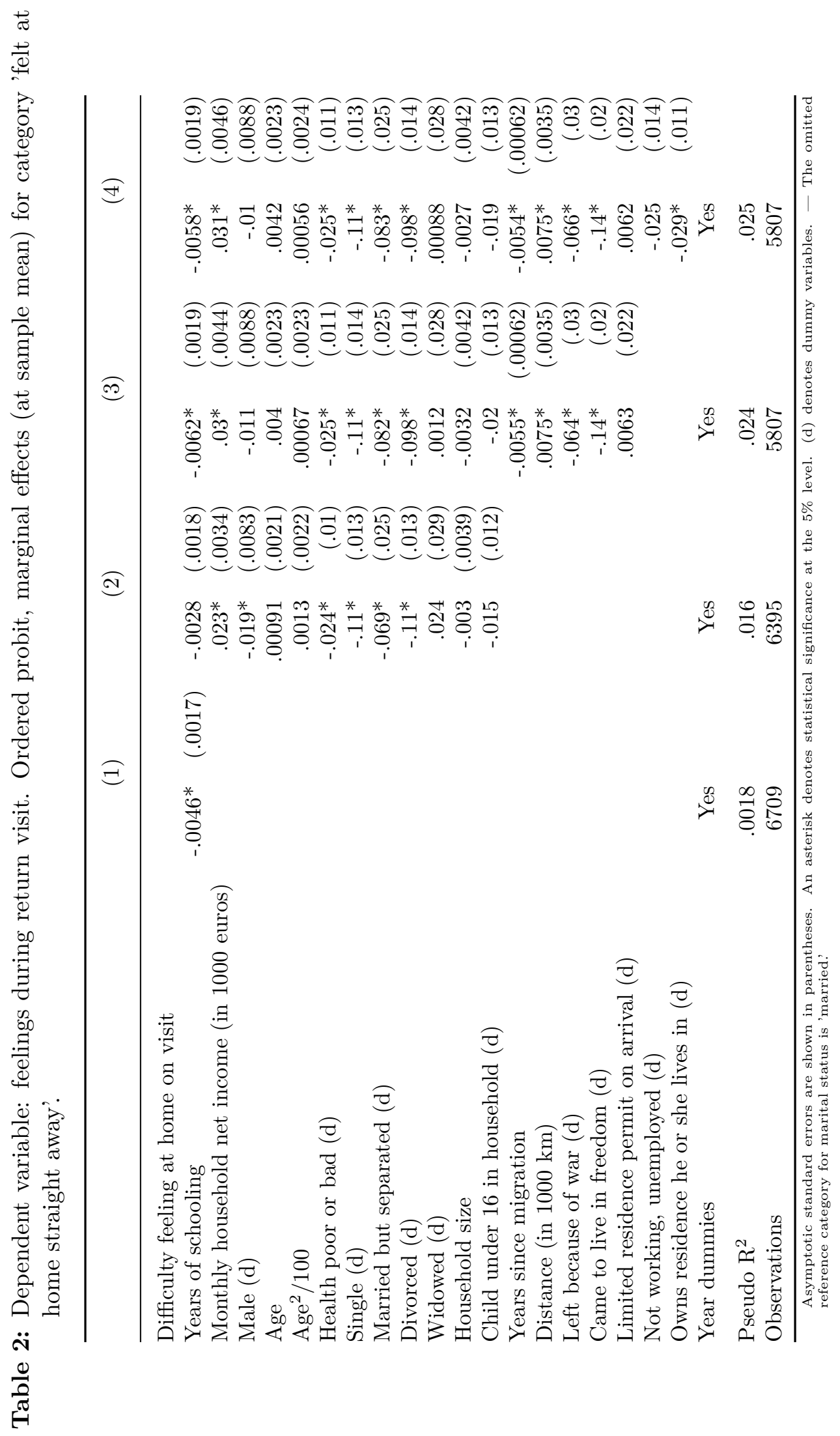


reference income is not observed in existing large $N$ data sets, I have extended their model to establish a link between immigrants' reference income and their return visits to their countries of origin. I have derived the two (arguably counter-intuitive) predictions that more educated immigrants are less likely to have returned to their country of origin for a visit, and that they are more likely to have difficulty feeling at home when they do return for a visit. Both predictions are confirmed on four waves of data from the German Socio-Economic Panel. The estimated marginal effects are statistically significant, but rather small in size. 


\section{References}

Clark, A. E., P. Frijters, and M. A. Shields (2008). Relative income, happiness, and utility: an explanation for the Easterlin paradox and other puzzles. Journal of Economic Literature 46, 95-144.

D'Ambrosio, C. and J. R. Frick (2007). Income satisfaction and relative deprivation: An empirical link. Social Indicators Research 81, 497-519.

Falk, A. and M. Knell (2004). Choosing the Joneses: endogenous goals and reference standards. Scandinavian Journal of Economics 106, 417-435.

Ferrer-i-Carbonell, A. (2005). Income and well-being: An empirical analysis of the comparison income effect. Journal of Public Economics 89, 997-1019.

Luttmer, E. F. P. (2005). Neighbors as negatives: Relative earnings and well-being. Quarterly Journal of Economics 120(3), 963-1002.

Manski, C. F. (2000). Economic analysis of social interactions. Journal of Economic Perspectives 14, 115-36.

McBride, M. (2001). Relative-income effects on subjective well-being in the cross-section. Journal of Economic Behavior and Organization 45, 251-278.

Schwarze, J. and M. Härpfer (2007). Are people inequality averse, and do they prefer redistribution by the state? Evidence from German longitudinal data on life satisfaction. Journal of Socio-Economics 36, 233-49.

Schwarze, J. and R. Winkelmann (2005). What can happiness research tell us about altruism? Evidence from the German Socio-Economic Panel. Discussion Paper 1487, IZA, Bonn.

Stark, O. (1991). The Migration of Labour. Oxford: Blackwell.

Wagner, G. G., J. R. Frick, and J. Schupp (2007). The German Socio-Economic Panel Study (SOEP): Scope, evolution and enhancements. Schmollers Jahrbuch 127, 139169.

Wood, J. V. and K. L. Taylor (1991). Serving self-relevant goals through social comparison. In J. Suls and T. A. Wills (Eds.), Social comparison: contemporary theory and research. Hillsdale, NJ: Lawrence Erlbaum Associates. 


\section{A Appendix}

Table 3: Summary statistics

\begin{tabular}{lrrrrr}
\hline Variable & Mean & SD & Min & Max & N \\
\hline Ever visited country of origin & 0.91 &. & 0 & 1 & 7702 \\
Difficulty feeling at home on visit & 2.34 & 1.10 & 1 & 5 & 7122 \\
Years of schooling & 10.05 & 2.48 & 7 & 18 & 7348 \\
Male & 0.50 &. & 0 & 1 & 7822 \\
Age & 44.17 & 14.21 & 17 & 88 & 7822 \\
Not working, unemployed & 0.10 &. & 0 & 1 & 7822 \\
Owns residence he or she lives in & 0.20 &. & 0 & 1 & 7822 \\
Household size & 3.43 & 1.52 & 1 & 13 & 7822 \\
Child under 16 in household & 0.48 &. & 0 & 1 & 7822 \\
Single & 0.10 &. & 0 & 1 & 7786 \\
Married & 0.80 &. & 0 & 1 & 7786 \\
Married but separated & 0.02 &. & 0 & 1 & 7786 \\
Divorced & 0.05 &. & 0 & 1 & 7786 \\
Widowed & 0.03 &. & 0 & 1 & 7786 \\
Years since migration & 22.44 & 10.44 & 0 & 52 & 7066 \\
Distance to Frankfurt (in km) & 1965.68 & 1364.35 & 192 & 16468 & 7730 \\
Health poor or bad & 0.20 &. & 0 & 1 & 7808 \\
Monthly household net income & 2314.30 & 1776.31 & 183 & 101522 & 7460 \\
Family abroad & 0.98 &. & 0 & 1 & 820 \\
Left because of war & 0.02 &. & 0 & 1 & 7822 \\
Came to live in freedom & 0.02 &. & 0 & 1 & 7822 \\
Limited residence permit on arrival & 0.07 &. & 0 & 1 & 7822 \\
Year = 1996 & 0.22 &. & 0 & 1 & 7822 \\
Year = 1998 & 0.19 &. & 0 & 1 & 7822 \\
Year = 2000 & 0.24 &. & 0 & 1 & 7822 \\
Year = 2002 & 0.19 &. & 0 & 1 & 7822 \\
Year = 2004 & 0.16 &. & 0 & 1 & 7822 \\
\hline
\end{tabular}

Note: GSOEP 1996, 1998, 2000, 2002, 2004. Real income is in 2005 euros. 


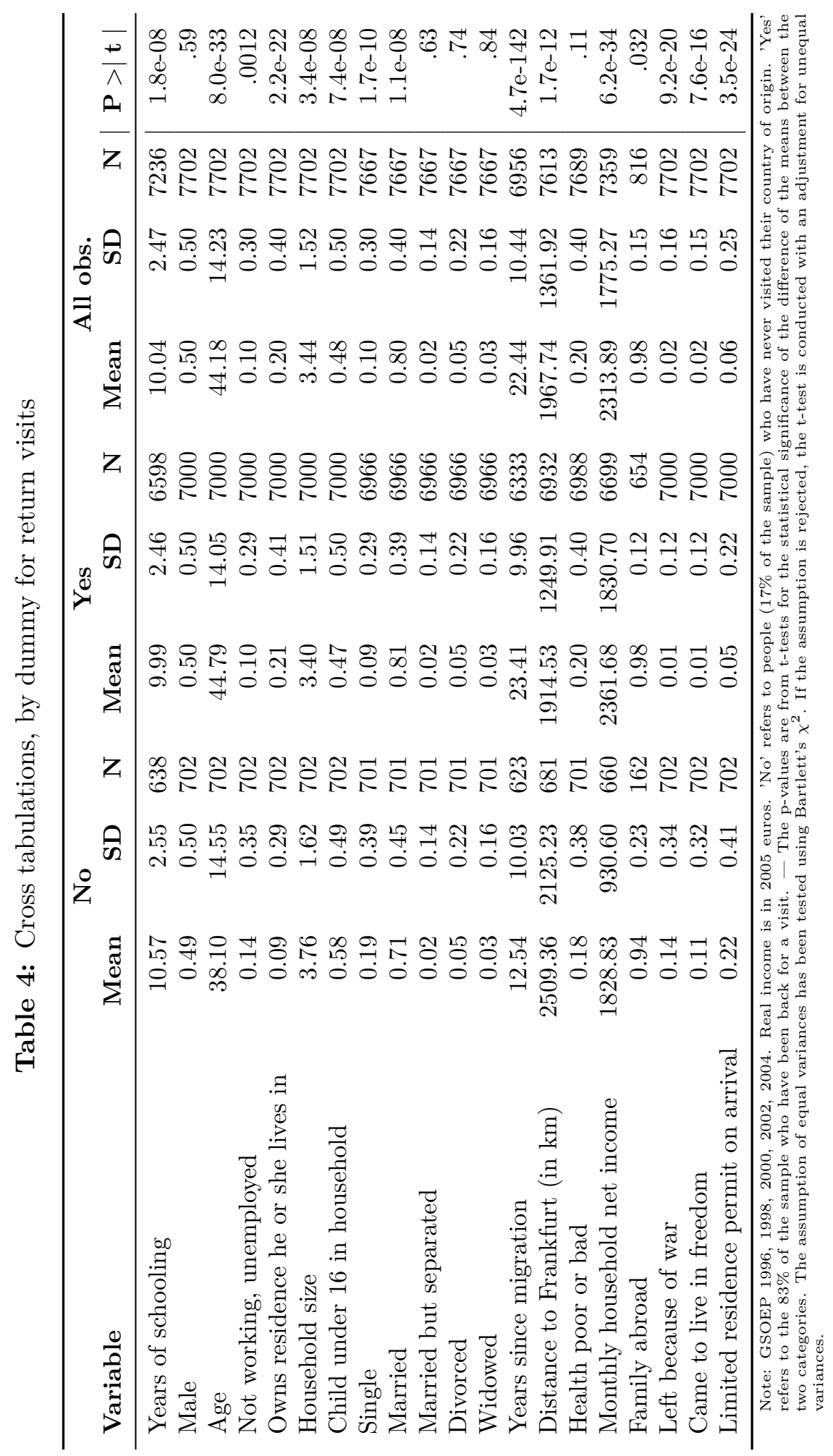




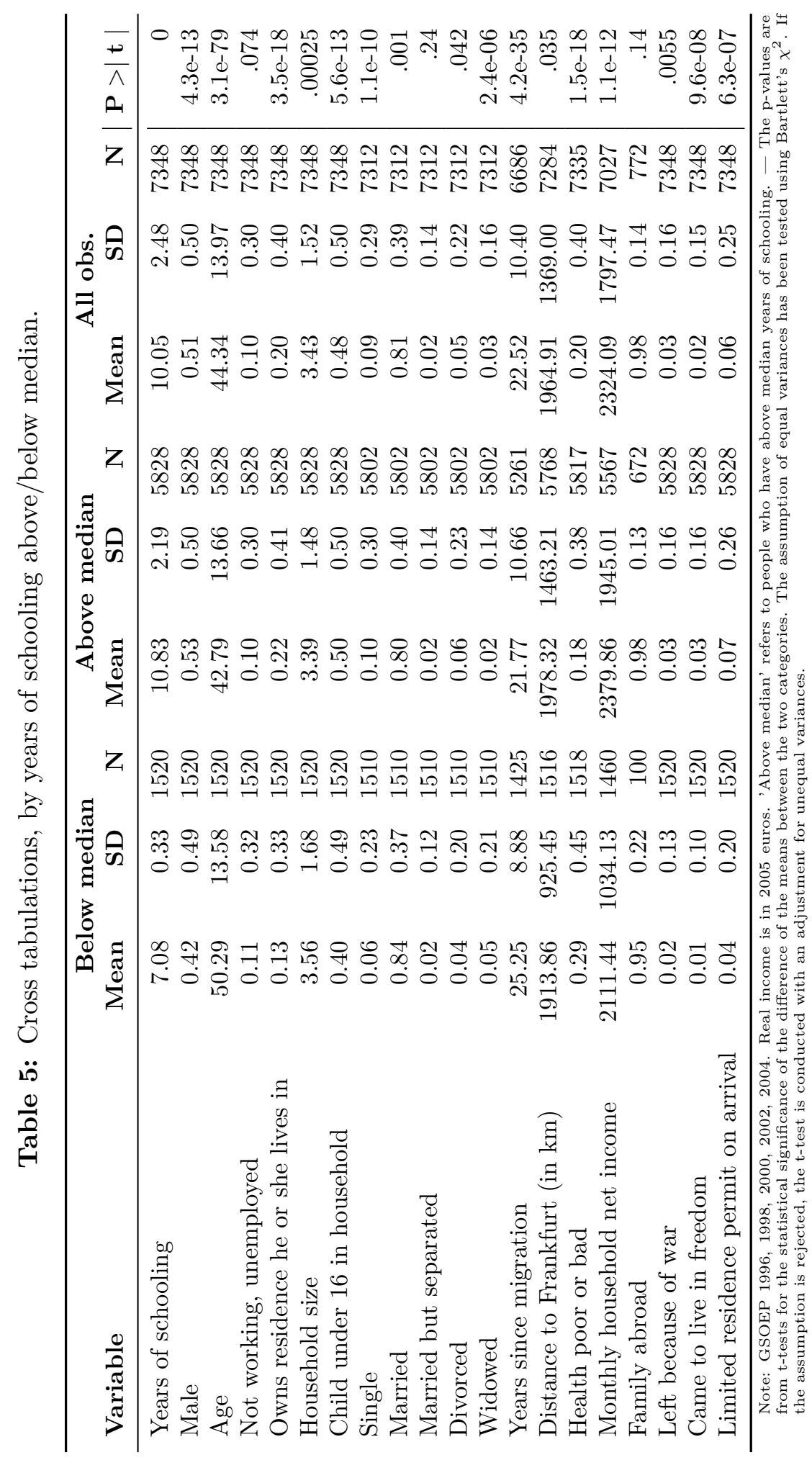




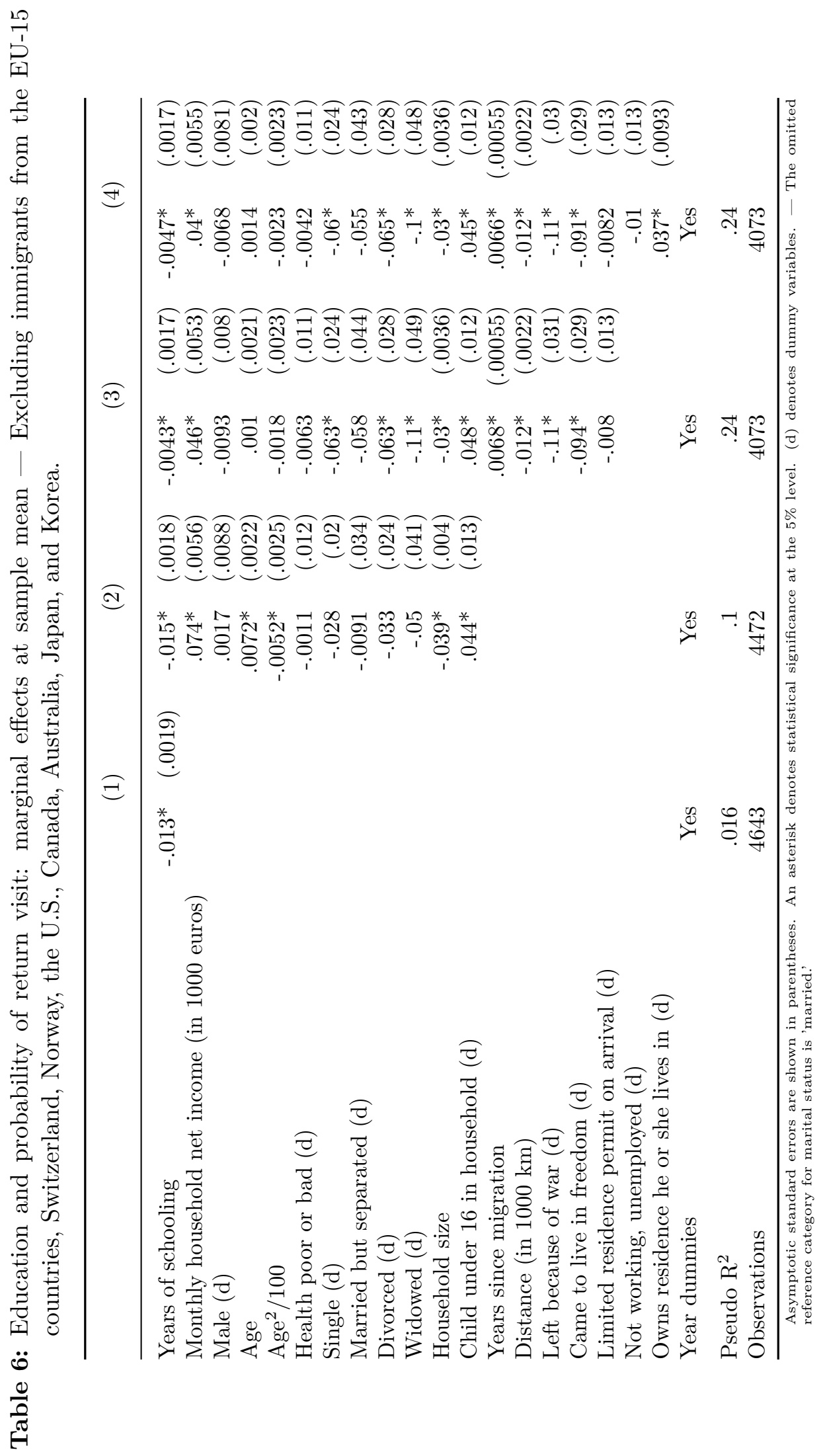




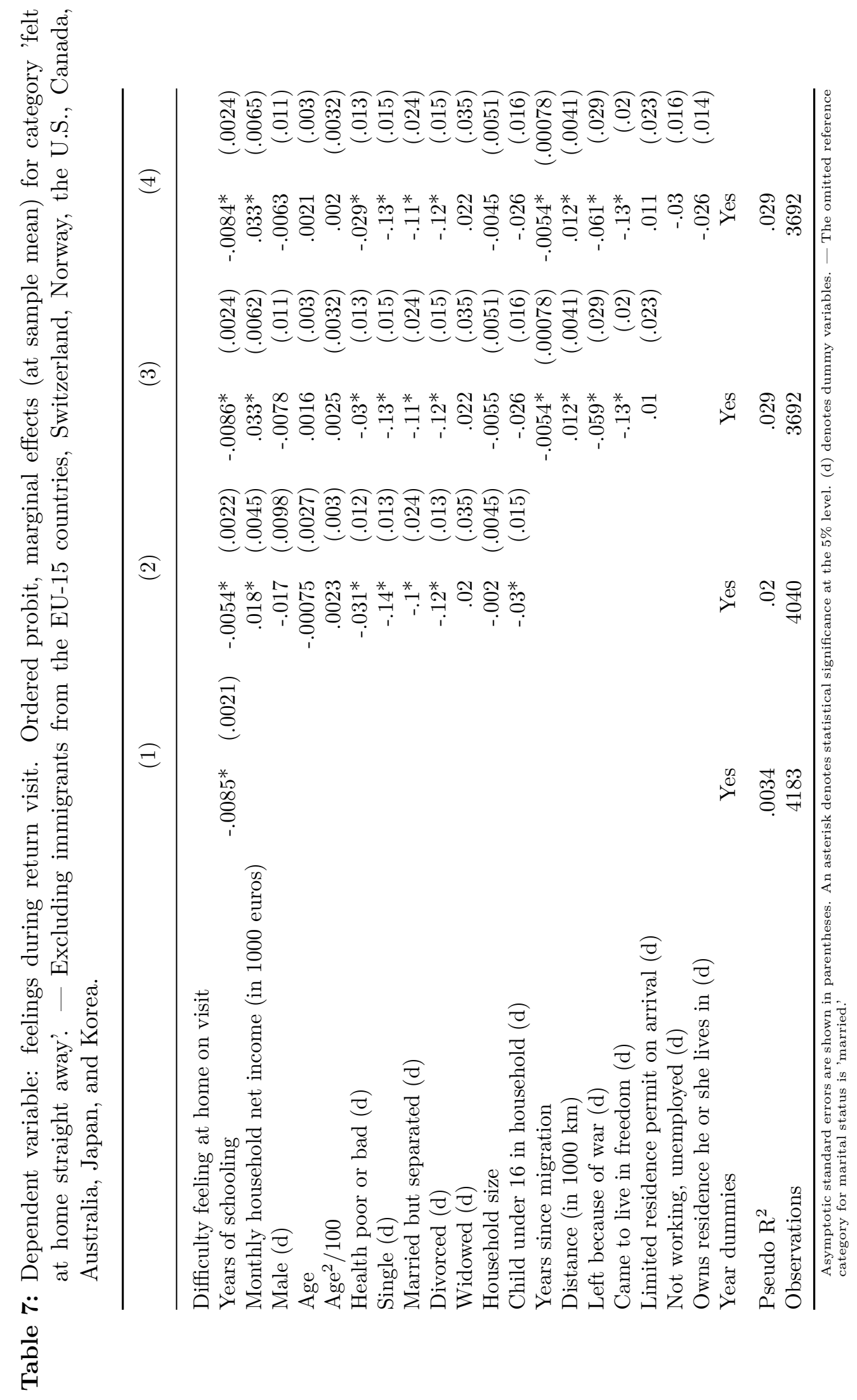

